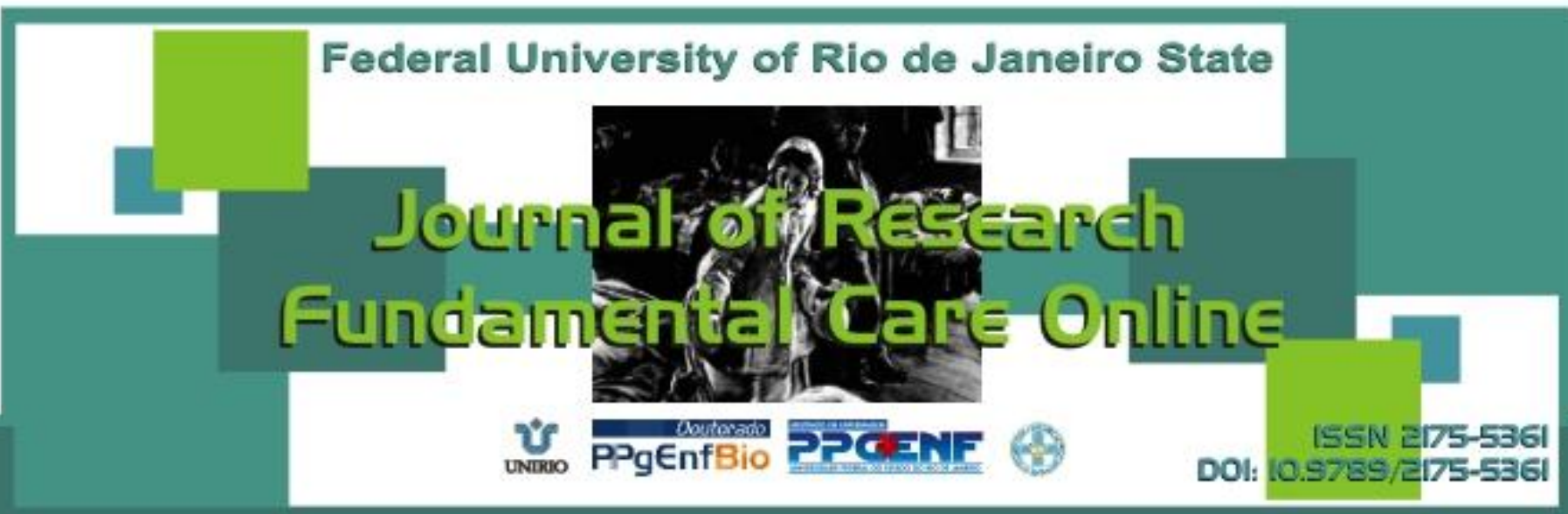

\title{
RESEARCH
}

\section{Assessment and classification of family risk in a school of early childhood education}

Avaliação e classificação do risco familiar em uma escola de educação infantil

Evaluación y clasificación del riesgo familiar en una escuela de educación infantil

Sueli Maria dos Reis Santos ${ }^{1}$, Maria Cristina Pinto de Jesus ${ }^{2}$, Letícia Souza Peyroton ${ }^{3}$, Fernanda Silva Linhares ${ }^{3}$

ABSTRACT

Objective: To evaluate the familial risk for children of early childhood education to support educational practices and school-family integration. Method: This exploratory, descriptive quantitative. The data collection was performed in a school in a city in Minas Gerais, 2011. The subjects were 69 school families. We used a form with topics related to socioeconomic factors and clinical conditions of the members of the families concerned. The data was submitted to statistical analysis with variable frequency, enabling the establishment of priorities (risk level, sentries and factors influencing the risks). Results: The familial risk was between low and medium, the clinical criterion influence this classification. There is potential for development of chronic diseases such as hypertension, obesity, alcoholism, smoking, and psychosocial disorders. Conclusion: The classification provided to identify the need for health education in the pursuit of generating content and collective actions to raise awareness for the acquisition of healthy habits. Descriptors: Health care, Children's health, Family, Education, Health.

RESUMO
Objetivo: Avaliar o risco familiar de crianças da educação infantil para subsidiar práticas educativas
e integração escola-família. Método: Pesquisa exploratória descritiva, quantitativa. Coleta de dados
realizada em uma escola de um município de Minas Gerais, em 2011 . Os sujeitos foram 69 famílias da
escola. Utilizou-se um formulário com tópicos relacionados a fatores socioeconômicos e condições
clínicas dos membros das famílias em questão. Submeteram-se os dados à análise estatística com
frequência das variáveis, possibilitando o estabelecimento de prioridades (grau de risco, sentinelas e
fatores que influenciam os riscos). Resultados: O risco familiar ficou entre baixo e médio, o critério
clínico influenciou esta classificação. Observou-se potencial para desenvolvimento de doenças
crônicas não transmissíveis, como: hipertensão arterial, obesidade, alcoolismo, tabagismo, além de
transtornos psicossociais. Conclusão: A classificação propiciou identificar a necessidade de realizar
práticas educativas em saúde, na busca de gerar conteúdos e ações coletivas voltadas para
sensibilização para aquisição de hábitos saudáveis. Descritores: Atenção à saúde, Saúde da criança,
Família, Educação, Saúde.

\section{RESUMEN}

Objetivo: Evaluar el riesgo familiar para los niños de educación infantil para apoyar las prácticas educativas y la integración escuela-familia. Método: Exploratorio, descriptivo cuantitativo. La recolección de datos en una escuela en una ciudad en Minas Gerais en 2011. Los sujetos fueron 69 familias de la escuela. Se utilizó un formulario con los temas relacionados con los factores socioeconómicos y las condiciones clínicas de los miembros de las familias afectadas. Sometidos los datos a un análisis estadístico con una frecuencia variable, lo que permite el establecimiento de prioridades (nivel de riesgo, los centinelas y los factores que influyen en los riesgos). Resultados: El riesgo familiar fue entre baja y media, el criterio clínico influye esta clasificación. Existe un potencial para el desarrollo de enfermedades crónicas como la hipertensión, la obesidad, el alcoholismo, el tabaquismo y los trastornos psicosociales. Conclusión: La clasificación proporcionada a identificar la necesidad de educación para la salud en la búsqueda de la generación de contenidos y acciones colectivas para aumentar la conciencia para la adquisición de hábitos saludables. Descriptores: Atención a la salud, Salud de los niños, Familia, Educación, Salud.

${ }^{1}$ Nurse. PhD Associate. Department Maternal-Child Nursing and Public Health. School of Nursing. Federal University of Juiz de Fora. Juiz de Fora, Minas Gerais, Brazil. Researcher at the Center for Interdisciplinary Research in Health Care (NUPIAS). Email: @ sueli.santos ufjf.edu.br. ${ }^{2}$ Nurse. PhD Associate. Basic Nursing Department. School of Nursing. Federal University of Juiz de Fora. Juiz de Fora, Minas Gerais, Brazil. Researcher at the Center for Interdisciplinary Research in Health Care (NUPIAS). Email: @ mariacristina.jesus ufjf.edu.br. ${ }^{3}$ Nursing Student. School of Nursing. Federal University of Juiz de Fora. Scientific Initiation Scholarship / UFJF. Juiz de Fora, Minas Gerais, Brazil. E-mail: lelepeyroton@hotmail.com nanda.enf.fortuna@gmail.com 


\section{INTRODUCTION}

ducation and health are social rights under the Constitution of 1988 , in accordance with Article 6, both are equally right and duty of the State, as advocated in the articles 196 and 205 of the same Constitution. Such constitutional principles find resonance on educational legislation. The Law of Guidelines and Bases of National Education, Law 9.394/1996 (LDB), which provides in Article 2, the fundamental rights of children and adolescents, including the right to life and health. This warranty is also recommended by the Child and Adolescent-ACE (Law 8069 of July 13, 1990), which, among other devices, details the necessary care to children and adolescents and the obligations of the Government and the System Unified Health System-SUS. ${ }^{1-4}$

As statistics from the Ministry of Education, registered in the Basic Education Census 2011, 2.298.707 children were enrolled in day care centers and other 4.681.345 in preschool, in 2011. ${ }^{5}$ Most of these children are exposed to risks and relationships of vulnerability, health problems due to dietary imbalances, exposure to diseases associated with sanitation conditions and socioeconomic, and family violence and urban. Such situations require action school, health services and family with a view to integration necessary to minimize the risks and vulnerability in this population group. ${ }^{6}$

The family is the first social institution responsible for the realization of the basic rights of children, so it is necessary to establish an open, participatory between school and family, making them partners in physical and intellectual development of children. The family structure, as well as the society has undergone changes that pose challenges for educational institutions. Therefore it is important to create conditions for constructive interaction with these families to enable their effective participation in the school.

The health needs of the population and is related to the conditions of life, historical traditions, habits and representations of the body, health and disease. ${ }^{7}$ The school is considered a privileged space for practices that promote health, preventive and health education.

The articulation between school and health unit is recommended and is configured as an important demand of the school community. To implement a model of care focused on the interests of users and to be able to meet their health needs, it is essential to guarantee spaces for knowledge exchange and collective construction involving the school, the health unit and the family. ${ }^{8}$

With the active participation of those involved in early childhood education and health care, it is possible to envision a school focused on the formation of critical citizens, informed and prepared to act in defense of life and its quality.

\section{OBJECTIVE}

The following question guided this study: What is the familial risk of children in early childhood education from a school in North Zone of Juiz de Fora? 
This study aims to assess familial risk children in early childhood education, using the scale of risk assessment. ${ }^{9}$

\section{METHODOLOGY}

This is a qualitative, descriptive and exploratory research, developed in the catchment area of a FHU located in the state of Rio Grande do Sul. By cover a territory extensive, this FHU is divided into two areas, each with six micro areas. It is worth mentioning that the micro areas have large socioeconomic and cultural disparities, configuring a heterogeneous territory.

Therefore, we chose to follow the guidelines for authors in terms of diversification of data. In qualitative research, diversification is the main selection criterion, as these are used in order to present the complete picture possible of the problem. ${ }^{9}$ Thus, given the diversification criterion, we tried to choose users from different micro areas, so that, if it came to the greatest possible diversity in view of their socioeconomic differences.

The choice of participants was guided by the following inclusion criteria: having hypertension, to be older than 18 and reside in micro areas of FHU. The search started from the master record of the families of Community Health Agents The number of study subjects was defined by data saturation, which marks the time when the search for new participants is not new for the research. ${ }^{9}$

For data collection we used semi structured interview consists of two parts. The first addressed questions about the socioeconomic characteristics of the participants and the second, questions about the practice of care for hypertension. The interviews took place in February and March 2011 and data were analyzed using thematic analysis, which consists in discovering the meaning units that make up a communication. ${ }^{10}$

Understanding the need to ensure and enhance the ethical conduct throughout the course of the study, we considered the guidelines and rules of Resolution 196/96 of the National Health Ministry of Health, governing research involving humans. ${ }^{11}$ Thus, the study was conducted with the approval of the municipality and the institutional Ethics Committee in Research of the Federal University of Santa Maria, under the Certificate of Appreciation Presentation for Ethics 0326.0.243.000-10 number.

To preserve the identity of the subjects was used the letter "S" of the subject, then the number on the order of the interview (S1, S2, and so on). All participants read and signed the consent form. 


\section{RESULTS AND DISCUSSION}

The characterization of the families of the school community, it was observed that females predominated $(92,7 \%)$, which was responsible for providing information about the family. In terms of age, 56,25\% of women were aged between 19-35 years. Regarding marital status, 45,31\% reported being married. Regarding education, 35,9\% of women had high school. Table 1 shows the characteristics of the representatives of the families.

Table 1: characterization of the participants of the study according to the gender. Juiz de Fora, 2011

\begin{tabular}{lcc|c}
\hline Variables & & Female $\mathrm{n}=64(92,7 \%)$ & Male $\mathrm{n}=5(7,3 \%)$ \\
\hline Age & $19-35$ & $36(56,25 \%)$ & - \\
& $36-53$ & $21(32,81 \%)$ & $5(100 \%)$ \\
& $>53$ & $2(3,1 \%)$ & - \\
Marital & Non informed & $5(7,8 \%)$ & $4(80 \%)$ \\
Status & Married & $29(45,31 \%)$ & - \\
& Stable Union & $9(14,06 \%)$ & $1(20 \%)$ \\
& Single & $16(25 \%)$ & - \\
& Separated & $7(10,93 \%)$ & - \\
Schooling & Divorced & $3(4,68 \%)$ & $2(40 \%)$ \\
Basic & Widow & & $1(20 \%)$ \\
Medium & Complete & $11(17,18 \%)$ & $1(20 \%)$ \\
Upper & Incomplete & $20(31,25 \%)$ & - \\
& Complete & $23(35,9 \%)$ & $1(20 \%)$ \\
& Incomplete & $2(3,12 \%)$ & - \\
\hline
\end{tabular}

In relation to the profession/occupation of the participants, $44,9 \%$ (31) defined themselves as "home". Of these, the majority (19) have one or two children, with a family income less than two minimum wages $(31,8 \%)$. In relation to sociodemographic variables, it was found that four families $(5,7 \%)$ had no public water supply in their homes and used water from a well or spring.

Figure 1 shows that $94,2 \%(65)$ of the families have been identified as no risk in relation to sociodemographic classification. Regarding the clinical classification criteria, the majority was classified as low to medium risk $(47,8 \%)$. In the case of familial risk, $62.3 \%$ were classified as low to medium.
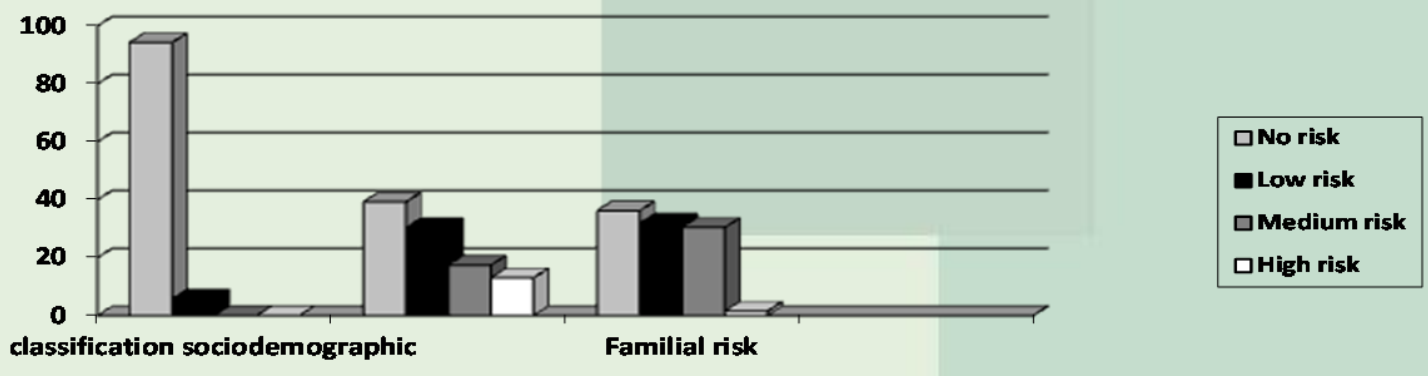
Figure 1 - Classification sociodemographic, clinical and familial risk children and families of employees of the Municipal School of North Zone of Juiz de Fora - 2nd half of 2011.

Regarding the terms of clinical risk, there was identified in the group of children, especially nutritional disorder (malnutrition and obesity) and among adolescents, obesity.

Were detected among older adults, health-risk situations, such as alcoholism, smoking, obesity, diabetes, hypertension, dyslipidemia, sequelae of stroke, depression, chronic kidney disease and polypharmacy. The psychological and psychiatric disorders, emphasizing depression, also stood out as the situation that affects more adults.

Although not considered in the instrument as clinical risk, it was possible to identify the group of children clinical situations of acute respiratory failure (sinusitis, rhinitis, bronchitis and asthma), urinary tract infection, cardiac abnormalities (murmurs) and traces of sickle cell anemia. In adolescents, there were obesity, asthma and urinary tract infection. In the adult group, found thyroid cancer, limb amputations due to circulatory problems and urinary tract infection. As for the elderly, we detected the presence of cancer and dermatological language as well as changes in the prostate. Identified that family members continue self-medicating, but only two seniors make use of multiple drugs.

Participants were 64 women $(92,7 \%$ of participants), this points to the fact that the responsibility for key aspects of child development, such as daily hygiene care, food and schooling still remains higher Mothers that parent. ${ }^{11}$

The predominance of women in fertile age range considered in relation to reproduction (56,25\% were aged $19-35$ years old) reveals the importance of awareness of the same in relation to birth, after all, when such mothers become more informed regarding the health and care to be taken with children, they become more responsible with regard to the control of the number of children, once they know the responsibility and financial costs that the creation of these requires.

There are still considering that a significant number of women participating in this study had no partner $(40.63 \%)$. In this respect, one realizes the extent of the role that meet their families, because they still bear alone with the main responsibilities of caring for children without help from teammates and support a network of public services such as schools and daycare centers in period integral. ${ }^{12}$

It is worth noting that women who live without partner gained more independence and, therefore, can take their families. However, this association ultimately strengthen lot more adjectives such as vulnerable families or risk that potentially autonomous. ${ }^{12}$

The way the mother devotes her attention to the children, either directly or through caregivers, as well as their access to health services is influenced by education level. Added to this is that low maternal education is still associated with higher rates of malnutrition, with twice the chance of occurrence of this in comparison with those of higher education. ${ }^{13}$

Regarding this fact, it is noted that all the women who participated in the study were literate, $48.43 \%$ having education at or above the high school and $31.25 \%$ with less than eight years of study.

The main strategy of targeted policies focusing on families has been the direct delivery of goods or training activities that reinforce the skills considered appropriate to 
housewives and mothers not working. ${ }^{12}$ In the analysis of socio-demographic variable profession/occupation, it was found that 31 women reported being "home" and three did not answer this question.

In this study it was found that among the women participants, only one has more than five children and $71,8 \%$ (46) have $1-2$ children. It was also observed that 11 women who have more than three children have the occupation function of being housewives and mothers not working. A wide variety of studies have presented evidence that women who take on the search for new knowledge, or seek higher education, and invest in their studies the delay pregnancy plans, leading to declining birth rates in women with more years of education. ${ }^{13-14}$

Also in Brazil, several studies have documented this evidence, suggesting that the level of education of the mother explains much of the fertility decline in Brazil ${ }^{14 .}$

In terms of family income, 69,9\% (39 families) had income between one and two minimum wages, while $12,5 \%$ live on less than minimum wage. Thirteen families have a family income of more than three minimum wages. These data demonstrate that the majority of families in this study can be classified as belonging to the class "E", according to the categorization made by the Brazilian Institute of Geography and Statistics (IBGE), which, based on the number of salaries, thus classifies Brazilian families: up to two minimum wages - Class E, two to four salary - Class D, four to ten - Class C; ten to 20 - Class $B$ and above 20 minimum wages - Class A. ${ }^{15 .}$

One of the sociodemographic variables for classification is basic sanitation, and detected an increase in access to a significant percentage of households to water services, sewage and garbage collection. ${ }^{13}$ However there is still a portion of the population that does not have these services.

In the classification sociodemographic, the present study, it was found that most of the families were classified as risk-free and only three families showed poor sanitation.

Regarding the classification of clinical criteria, which addresses elements of family health problems, the ratings average risk and high risk highlights. This result can anchor in the absence of health care practices and weaknesses in beliefs, since the values attributed to the attitudes and behaviors such as diet, physical activity, recreation and use of substances such as tobacco and alcohol are experienced and learned in the family. ${ }^{16}$

It is noteworthy that the family and the environment in which the child lives has a great influence not only in his recovery from health, but also in its development. ${ }^{17}$ When the family does not assign value to health promotion and there is an absence of a culture of prevention to injuries, she inserts the biomedical model of care in which family attendance is verified due to the emergence of a disease in one of its members and is rarely seen as a group of people who need evaluation and intervention. ${ }^{18}$

The role of nurses in family health implies relate all social, economic and cultural presented, not only to deal with the situations of health and illness in the family, but also interact with situations that seek the full family. Diagnoses and interventions in a family member reflect on health promotion for all familiar core. ${ }^{19}$

In this study, the classification of the Family Risk, which is the sum of the classification with the classification of sociodemographic, clinical, presented as a result of 
significant risk and low average risk families. The main factor that contributed to this classification was the clinical criterion.

These results were presented at a meeting with parents and school staff. Based on this classification, it was possible to discuss strategies to promote health from the risk of harm to herself and the process of learning in early childhood education focuses on the development of healthy habits. It envisioned the possibility of planning and conducting educational workshops with the school community. Faced with this possibility, most participants showed up excited and willing to accept the proposal.

\section{CONCLUSION}

The study was adequate to perform the assessment of risk family of children in early childhood education, resulting in the classification of the familial risk. This result supported the construction of proposed educational workshops for families, teachers and school staff, as a space for the theming and content generation and collective actions aimed at integrating health school. The proposal for the creation of the Parent's School comes precisely to pose as a support for families to obtain information about various topics and is closer to the school, thus allowing a more open dialogue and dynamic. In the workshops, several issues may be addressed in order to construct a concept of health promotion and disease prevention in the family and at school.

\section{REFERENCES}

1. Brasil. Lei n. 8.069, de 13 de julho de 1990. Atualizada em outubro de 2009. Dispõe sobre o Estatuto da Criança e do Adolescente e dá outras providências. [acesso em: 01/11/2012]. Disponível em: http://www.planalto.gov.br/ccivil_03/leis/L8069.htm

2. BRASIL. Lei n. 9.394, de 20 de dezembro de 1996. Estabelece as diretrizes e bases da educação nacional. [acesso em: 01/11/2012]. Disponível em: http://www.planalto.gov.br/ccivil_03/LEIS/L9394.htm.

3. BRASIL. Constituição (1998). Constituição da República Federativa do Brasil. Brasília, DF: Senado Federal, 1988.

4. Amarante AG, Soares M, Cássia B. Adolescência no SUS: uma revisão bibliográfica. São Paulo, Brasil. Rev. bras. crescimento desenvolv. hum. 2007; 17(3): 154-9.

5. Acervo Digital Veja [homepage na internet]. Valor de merendas em creche e pré-escola é reajustado. [acesso em: 01 nov 2012]. Disponível em: 
http://veja.abril.com.br/noticia/educacao/valor-de-merendas-em-creche-e-pre-escola-ereajustado.

6. Bertolozzi MR, Nichiata LYI, Takahashi RF, Ciosak SI, Hino P, Val LF et al . Os conceitos de vulnerabilidade e adesão na Saúde Coletiva. Rev Esc Enferm USP. [periódico na Internet]. 2009 dez [citado 2012 nov 13]; 43(spe2): 1326-1330. Disponível em: http: / / www.scielo.br/scielo.php?script=sci_arttext\&pid=S0080-

$62342009000600031 \&$ lng=es. http://dx.doi.org/10.1590/S0080-62342009000600031.

7. Câmara AMCS, Melo VLC, Gomes MGP, Pena BC, Silva AP; Oliveira KM et al.

Percepção do processo saúde-doença: significados e valores da educação em saúde. Rev. bras. educ. med. [online]. 2012, vol.36, n.1, suppl.1, [citado 2012-12-05],pp. 40-50. Disponível em: http://www.scielo.br/scielo.php?script=sci_arttext\&pid=S010055022012000200006\&lng=pt\&nrm=iso>. ISSN 0100-5502. http://dx.doi.org/10.1590/S010055022012000200006.

8. Ministério da Saúde (BR). Entrevista Adib Jatene, diretor do HCor e ex-ministro da Saúde Eugênio Vilaça, consultor em Saúde Pública. Revista Brasileira Saúde da Família. 2008; 9 (19):4-10, Brasília:Ministério da Saúde.

9. Coelho FLG, Savassi LCM. Aplicação da escala de risco familiar como instrumento de priorização das visitas domiciliares. Rev Bras Med Família Comum. 2004; 1 (2):19-26.

10. Implantação do Plano Diretor da Atenção Primária a Saúde. Escola de Saúde Pública de Minas Gerais- Belo Horizonte: ESPMG, 2009.

11. Cia F, Pamplin RCO, Del Prette ZAP. Comunicação e participação pais-filhos: correlação com habilidades sociais e problemas de comportamento dos filhos. Ribeirão Preto. Paidéia (Ribeirão Preto). 2006; 16(35): 395-406. [acesso em 01 nov. 2012]. Disponível em: http: //www.scielo.br/scielo.php? Script =sci_arttext\&pid= S01 03-863X2006000300010\&lng =pt\&nrm=iso. http:// dx.doi.org/10.1590/S0103-863X2006000300010.

12. Carloto $\mathrm{CM}$. Centralidade na família e centralidade nas mulheres? $2^{\circ}$ Seminário Nacional Estado e Políticas Sociais no Brasil [apresentação], UNIOESTE. Cascavel, Brasil. 2005.

13. Menezes RCE, Lira PIC, Leal VS, Oliveira JS, Santana SCS, Sequeira LAS et al . Determinantes do déficit estatural em menores de cinco anos no Estado de Pernambuco. São Paulo. Rev Saúde Pública. 2011; 45(6): 1079-87.

14. Lopes JL, Pontilli RM. Renda familiar e educação como fatores condicionantes do aumento da taxa de fertilidade: uma análise para o Paraná. Anais V ECOPAR - Encontro de Economia Paranaense (2007, out, 4-5); Curitiba, PR.

15. Instituto Brasileiro de Geografia e Estatística [homepage na internet]. Faixas salariais $x$ classe social - Qual sua classe social? [acesso em 01/11/2012]. Disponível em: http://blog.thiagorodrigo.com.br/index.php/faixas-salariais-classe-social-abep-ibge?blog=5. 16. Silva MCLSR; Silva L, Bousso RS. A abordagem à família na Estratégia Saúde da Família: uma revisão integrativa da literatura. São Paulo, Brasil. Rev Esc Enferm USP [online]. 2011; 45 (5):1250-5. ISSN 0080-6234. [acesso em 01/11/2012]. Disponível em: http://dx.doi.org/10.1590/S0080-62342011000500031.

17. Fonseca EL, Marcon SS. Percepção de mães sobre o cuidado domiciliar prestado ao bebê nascido com baixo peso. Brasília, DF. Rev Bras Enferm. 2011; 64(1):11-17.[acesso em 01/11/2012]. Disponível em http://www.scielo.br/scielo.php?script=sci_arttext\&pid=S0034$71672011000100002 \& \operatorname{lng}=$ pt\&nrm=iso> . 
18. Moura LS, Kantorski LP, Galera SAF. Avaliação e intervenção nas famílias assistidas pela equipe de saúde da família. Porto Alegre, RS. Rev Gaúcha Enferm. 2006; 27 (1):35-44.

19. Amaral RFC, Souza T, Melo TAP, Ramos FRS. Itinerário terapêutico no cuidado mãefilho: interfaces entre a cultura e biomedicina. Rev Rene. 2012; 13(1):85-93. 